\section{$\angle$ Research Square}

Preprints are preliminary reports that have not undergone peer review.

They should not be considered conclusive, used to inform clinical practice, or referenced by the media as validated information.

\title{
Assessment of water quality status of hemodialysis treatment plants in Baghdad, Iraq
}

\author{
Yasamen Raad ( $\nabla$ yasmenraad@gmail.com ) \\ Ministry of science and technology https://orcid.org/0000-0002-7594-9531 \\ Saadi Al-Naseri \\ ministry of science and technology \\ Natheer Imran \\ ministry of science and technology \\ Mahdi Jaafar \\ ministry of science and technology
}

\section{Research Article}

Keywords: Water quality, Dialysis fluid, Hemodialysis treatment plant, Heavy elements, Trace metal

Posted Date: April 30th, 2021

DOI: https://doi.org/10.21203/rs.3.rs-457742/v1

License: (9) This work is licensed under a Creative Commons Attribution 4.0 International License. Read Full License 


\section{Abstract}

The chemical quality of the water used for dialysis fluid is a crucial factor for patients receiving dialysis. Therefore, strict monitoring of the quality of water is necessary in order to prevent complications and to guarantee the safety and health of patients. The current study aimed to determine the chemical water quality used in hemodialysis treatment plants and compare it to standards of the Association for advancement of medical instrumentation (AAMI) and International Organization for Standardization (ISO) in four hospitals in Baghdad. This cross-sectional study is performed in four seasons in 2019. This research was conducted on samples of dialysis water. Samples were tested by the spectrometry system (AA-7000, Shimadzu, Japan) and colorimeters DR890 for free chlorine. Microsoft 2010 was used for statistical analyses. Based on the results of the research, all concentrations of chemical compounds were within accepted international standards except free chlorine. Also, there were no significant differences between the measured parameters in the dialysis water at four treatment plants during the study period at $(P<0.05)$. The assessment of water quality hemodialysis showed that these hemodialysis treatment plants were not significantly contaminated and that the quality of the water met the AAMI and ISO standards.

\section{Introduction}

Dialysis water quality is the result of an integrated series of purification and disinfection systems [1]. Hemodialysis patients are exposed to a large amount of dialysis fluid (approximately 120 litters) in a single dialysis operation [2]. The presence of a semi-permeable non-selective membrane, which serves as a blood and dialysis fluid barrier, provides a direct route to the conversion of pollutants into the bloodstream. As a result, many of the approved amounts of chemical compounds in drinking water are potentially toxic to patients with dialysis [3]. Consequently, in the treatment plants with dialysis, proper facilities for water treatment must be prepared and the quality of dialysis water must be controlled [4].

The most common elements involved in renal toxicity are arsenic, barium, cadmium, cobalt, copper, lead, lithium, mercury, and platinum for the health and safety of patients with hemodialysis, it is important to ensure that the water used for dialysis is safe and clean [5], small amounts of these trace elements are required because they are essential factors and cofactors in many cellular biochemical processes, including the synthesis of nucleic acids and proteins and enzymatic reactions [6].

Ensuring that water quality follows the requirements and guidelines of the International Organization for Standardization (ISO) and similar standards of both the American National Standards Institute (ANSI) and the Association Instrumentation (AAMI) has provided standards and recommendations (or equivalent) are important to decrease the occurrence of chemical hazards associated with the use of hemodialysis water $[7,8]$. As a result, this will be adopted in this study to compare the quality of dialysis water produced because there is no national standard for the quality of dialysis water in Iraq. 
Therefore, the present study evaluated the quality of water used for dialysis in four hemodialysis treatment plants located within Baghdad to analyze the changes in concentrations of elements in the water dialysis used at different hospitals and to determine the role of RO membrane in the changes described.

\section{Methods}

\subsection{Work Strategy}

This study covers at four hemodialysis treatment plants in three hospitals located in Baghdad, Iraq namely: Baghdad Educational ( $\mathrm{H} 1$ and $\mathrm{H} 2)$, Private Nursing Home (H3), and Ghazi Al-Hariri Surgical $(\mathrm{H} 4)$. The sampling process included collecting water samples from treatment unit output (dialysis water). To evaluate chemical elements, sixteen samples were collected from each of the four hemodialysis treatment plant in four seasons (January to December) in the period of 2019. Water samples $(500 \mathrm{ml})$ were collected and transported to the laboratory for chemical analysis.

\subsection{Chemical elements Analysis}

The study of heavy elements was conducted in the laboratories of the Iraqi Ministry of Science and Technology using the graphite furnace atomic absorption spectrometry system (AA-7000, Shimadzu, Japan). Determination of heavy elements: aluminum, total chlorine, copper, fluoride, lead, nitrate (as $\mathrm{N}$ ), sulfate, and zinc. In addition, trace elements: antimony, arsenic, barium, beryllium, cadmium, chromium, mercury, selenium, silver, and thallium. Furthermore, using the N,N-diethyl-p-phenylene-diamine colorimetric method with the DR890 colorimeter, another parameter such as free chlorine was also measured.

\subsection{Statistical Analysis}

Analysis of the variance test (ANOVA) was used to determine the relevant effects of the various parameters at a significant P-value of 0.05 . The statistical analysis was conducted using Microsoft Excel 2010 .

\section{Results}

\subsection{Chemical analysis}

The results are showed with minimum and maximum indexes, and are compared with those of ANSI/AAMI and ISO (Tables 1 and 2). 
Table 1

Chemical analysis results of heavy elements contaminants for the four dialysis treatment plants

\begin{tabular}{|llllll|}
\hline Contaminant & $\begin{array}{l}\text { Standard water } \\
(\mathbf{m g} / \mathbf{l})\end{array}$ & $\begin{array}{l}\mathrm{H} 1 \\
(\text { Min-Max })\end{array}$ & $\begin{array}{l}\text { H2 } \\
(\text { Min-Max })\end{array}$ & $\begin{array}{l}\text { H3 } \\
\text { (Min-Max) }\end{array}$ & $\begin{array}{l}\text { H4 } \\
\text { (Min-Max) }\end{array}$ \\
\hline Aluminum & 0.01 & $\begin{array}{l}0.0003- \\
0.007\end{array}$ & $\begin{array}{l}0.0002- \\
0.009\end{array}$ & $\begin{array}{l}0.0013- \\
0.0099\end{array}$ & $\begin{array}{l}0.002- \\
0.014\end{array}$ \\
\hline Free Chlorine & 0.1 & $0-0.18$ & $0-0.06$ & $0-0.12$ & $0-0.07$ \\
\hline Copper & 0.1 & BDL-0.09 & BDL-0.08 & BLD-0.07 & BDL-0.08 \\
\hline Fluoride & 0.2 & $0.006-$ & $0.01-0.014$ & $0.002-0.01$ & $0.007-$ \\
\hline Lead & 0.005 & BDL-0.0004 & BDL-0.0003 & BDL-0.0001 & BDL-0.0002 \\
\hline $\begin{array}{l}\text { Nitrate (as } \\
\text { N) }\end{array}$ & 2 & $0.01-1.76$ & $0.03-1.33$ & $0.002-0.72$ & $0.01-0.83$ \\
\hline Sulfate & 100 & $0.008-4.4$ & $1.4-10.2$ & $0-0.8$ & $0-1.7$ \\
\hline Zinc & 0.1 & BDL-0.13 & BDL-0.04 & BDL-0.06 & BDL-0.031 \\
\hline BDL: Below Detection Limits & & & & \\
\hline
\end{tabular}


Table 2

Chemical analysis results of trace elements contaminants for the four dialysis treatment plants

\begin{tabular}{|c|c|c|c|c|c|}
\hline Contaminant & $\begin{array}{l}\text { Standard water } \\
(\mathrm{mg} / \mathrm{l})\end{array}$ & $\begin{array}{l}\text { H1 } \\
\text { (Min-Max) }\end{array}$ & $\begin{array}{l}\text { H2 } \\
\text { (Min-Max) }\end{array}$ & $\begin{array}{l}\text { H3 } \\
\text { (Min-Max) }\end{array}$ & $\begin{array}{l}\text { H4 } \\
\text { (Min-Max) }\end{array}$ \\
\hline Antimony & 0.006 & $\begin{array}{l}0.00027- \\
0.00066\end{array}$ & $\begin{array}{l}0.00033- \\
0.001\end{array}$ & $\begin{array}{l}0.00022- \\
0.001\end{array}$ & $\begin{array}{l}0.00038- \\
0.002\end{array}$ \\
\hline Arsenic & 0.005 & $\begin{array}{l}0.00018- \\
0.0004\end{array}$ & $\begin{array}{l}0.00024- \\
0.0006\end{array}$ & $\begin{array}{l}0.0002- \\
0.0008\end{array}$ & $\begin{array}{l}0.00016- \\
0.0007\end{array}$ \\
\hline Barium & 0.1 & BDL-0.0004 & BDL-0.0006 & BDL-0.001 & BDL-0.001 \\
\hline Beryllium & 0.0004 & $\mathrm{BDL}$ & BDL & $\mathrm{BDL}$ & BDL \\
\hline Cadmium & 0.0001 & $\begin{array}{l}0.00002- \\
0.00005\end{array}$ & $\begin{array}{l}0.00001- \\
0.00003\end{array}$ & $\begin{array}{l}0.00001- \\
0.00002\end{array}$ & $\begin{array}{l}0.00001- \\
0.0001\end{array}$ \\
\hline Chromium & 0.014 & $\begin{array}{l}0.00016- \\
0.00021\end{array}$ & $\begin{array}{l}0.00015- \\
0.0002\end{array}$ & 0.00027 & $\begin{array}{l}0.00014- \\
0.0002\end{array}$ \\
\hline Mercury & 0.0002 & BDL & BDL & $\mathrm{BDL}$ & $\mathrm{BDL}$ \\
\hline Selenium & 0.09 & $\begin{array}{l}0.0005- \\
0.001\end{array}$ & $\begin{array}{l}0.0003- \\
0.001\end{array}$ & $\begin{array}{l}0.0004- \\
0.001\end{array}$ & $\begin{array}{l}0.0005- \\
0.001\end{array}$ \\
\hline Silver & 0.005 & $\begin{array}{l}0.00005- \\
0.0009\end{array}$ & $\begin{array}{l}0.00004- \\
0.0006\end{array}$ & $\begin{array}{l}0.0002- \\
0.0007\end{array}$ & $\begin{array}{l}0.0001- \\
0.0009\end{array}$ \\
\hline Thallium & 0.002 & BDL & $\mathrm{BDL}$ & $\mathrm{BDL}$ & $\mathrm{BDL}$ \\
\hline
\end{tabular}

According to Table 1, there were no significant differences in heavy elements aluminum, free chlorine, copper, fluoride, lead, nitrate (as N), sulfate, and zinc across hemodialysis treatment plants in various hospitals (Pख0.05). In addition, all results of concentrations of the chemical compounds were lower than the international standards in $100 \%$ of the samples. Furthermore, results an estimated $31 \%$ of the treated water samples showed a low level of free residual chlorine that complies with international standards $(0.1 \mathrm{mg} / \mathrm{I})$ (ANSI/AAMI 23500, 2019 and ISO 23500, 2019). In many samples about 62\%, the recorded values were below the limits (i.e., $0 \mathrm{mg} / \mathrm{l}$ ).

According to Table 2, there was there were no significant differences in trace elements: antimony, arsenic, barium, beryllium, cadmium, chromium, mercury, selenium, silver, and thallium in any of the samples across hemodialysis treatment plants in various hospitals (Pख0.05). In other words, trace elements were within the limit in all of the samples, similar to those of heavy elements.

\section{Discussion}


In dialysis, the recommended maximum levels of chemical contaminants are the same as those for the water used for dialysate preparation. Long-term exposures to such chemical metal are harmful to dialysis patients, as the chemical concentration must not exceed the limits set out in (ISO 23500, 2019 and ANSI/AAMI 23500, 2019) [7, 8].

In this regard, the results of the present study were in line with those of some previous studies and did not match some others.

In a previous study by Humudat in Baghdad, Iraq, the characteristics of the water quality of the hemodialysis treatment plants in four hospitals were investigated. The results of this research showed that the concentration of free chlorine in all of the samples of dialysis water was not higher than standard limits, which comply with those of the current study [2]. While the lack of free chlorine in the treatment plants for dialysis water meant that there was initially an inadequate amount of chlorine applied to the water. The reasons for the different levels of municipal water may have been the disinfection methods of municipal water treatment plants and the climatic conditions during the study period [9].

In the current study, the concentration of aluminum was lower than standard limits in all the samples. The results of the study regarding the concentration of aluminum were not similar to the other study by researchers in Iraq. Their study on 18 compositions in the dialysis water showed that the concentrations of metal such as aluminum were higher than the standard limit $[9,10]$.

Researchers investigated the trace chemical quality of dialysis water and compared it with international standards for the hemodialysis treatment plants in other hospitals [11]. Results showed that the value of the measured parameters was significantly higher than the standard values due to the dialysis feed water can be a significant source of toxic trace elements that may accumulate due to high exposure, especially during hemodialysis. These results were not compatible with those of the current study.

In the study by Sandgol et al. [12] in Khatam-al-Anbia Hospital, the aluminum level in the dialysis water was higher than the standard while in this study, although all of the elements considered were significantly lower than the standard in this study.

Arvanitidou et al. [13] reported that the amount of nickel, iron, and aluminum in dialysis water was higher than the normal in 85 health centers in Greece. In addition, the analysis performed by Sobrino et al. on 30 elements in Mexico [14] showed that only aluminum was higher than the AAMI norm among the elements considered, while this problem was the opposite in the current study. However, the study by Pirsaheb et al. indicated that lead and chromium concentrations were increased in the water of the dialysis, which may be due to the higher concentration of the considered elements in the feed water of dialysis [15].

Reverse osmosis is capable of excluding metal ions, aqueous salts, and molecules from the water being treated [16]. In some hemodialysis treatments in the state of São Paulo, Brazil use pre-treatment components along with the reverse osmosis process to generate filtered water. Pretreatment is 
responsible for removing sediments, organic materials, minerals, and chlorine/ chloramine from incoming water [1].

\section{Limitations}

The research did not cover all the chemical and bacteriological contaminants specified in the ANSI/AAMI and ISO standard due to the limitation of the spectrophotometer method used and not provide endotoxin test for bacteriological.

\section{Conclusions}

The study highlights the enhancement in 2019 of the chemical quality of treated dialysis water, showing that water is a safe component of the treatment. It also emphasizes the importance of continuing regular monitoring of the production and the water system distribution of the dialysis services to assure the chemical quality standard for the dialysis water in order to prevent accumulate of toxic chemical in chronic renal patients. Compliance can be improved by updating disinfection procedures, regular disinfection of the water system, and validation of the water treatment system to meet the latest established quality standards requirements for dialysis water in Bagdad.

\section{Declarations}

\section{Acknowledgments}

Authors would like to thank the laboratory experts for their assistance in Environment \&water directorate, Ministry of Science and Technology in Baghdad, Iraq for their cooperation. And authors report no conflicts of interest. The authors alone are responsible for the content and writing of the paper.

\section{References}

1. Hilinski, E. G., Almodovar, A. A. B., Pinto, T. D. J. A., \& Bugno, A. (2020). Is dialysis water a safe component for hemodialysis treatment in São Paulo State, Brazil?. Brazilian Journal of Pharmaceutical Sciences, 56.

2. Humudat, Y R. (2020). Evaluating dialysis fluids properties and its effects on hemodialysis patients at several hospitals in Baghdad. Thesis of PhD. Collage of science-University of Baghdad, p. 207.

3. Shahryari, A., Nikaeen, M., Hatamzadeh, M., Dastjerdi, M. V., \& Hassanzadeh, A. (2016). Evaluation of bacteriological and chemical quality of dialysis water and fluid in Isfahan, Central Iran. Iranian journal of public health, 45(5), 650 .

4. Taleshi, M. S. A., Nejadkoorki, F., Azimzadeh, H. R., Namayandeh, S. M., Namayandeh, M. S., \& Ghaneian, M. T. (2015). The Quality of Dialysis Water: A Case Study in the Educational Hospitals of Yazd, Iran. Health Scope, 4(1), p. e23086. 
5. Humudat, Y. R., \& Al-Naseri, S. K. (2020). Heavy Metals in Dialysis Fluid and Blood Samples from Hemodialysis Patients in Dialysis Centers in Baghdad, Iraq. Journal of Health and Pollution, 10(27), p. 200901.

6. Lentini, P., Zanoli, L., Granata, A., Signorelli, S. S., Castellino, P., \& Dell'Aquila, R. (2017). Kidney and heavy metals-The role of environmental exposure. Molecular Medicine Reports, 15(5), 3413-3419.

7. SO 23500. (2019). International Organization for Standardization: Water treatment equipment for hemodialysis applications and related therapies: Switzerland.

8. ANSI/AAMI 23500. (2019). American National Standards Institute/ Association for the Advancement of Medical Instrumentation: Water treatment equipment for haemodialysis applications and related therapies. Switzerland, p. 1-33.

9. Humudat, Y., \& Al-Naseri, S. K. (2020). Evaluation of dialysis water quality at hospitals in Baghdad, Iraq. Journal of Health and Pollution, 10(28), p. 201211.

10. Al-Naseri, S. K., Mahdi, Z. M., \& Hashim, M. F. (2013). Quality of water in hemodialysis centers in B aghdad, I raq. Hemodialysis International, 17(4), 517-522.

11. Filler, G., \& Felder, S. (2014). Trace elements in dialysis. Pediatric Nephrology, 29(8), 1329-1335.

12. Sandgol, H., Rashidi, H., Zakeri, Z., Karim Koshteh, O., \& Komeil, G. H. (2004). Changes in serumaluminum after desferrioxamine test. Zahedan Journal of Research in Medical Sciences, 6(1), 53-58.

13. Arvanitidou, M., Spaia, S., Katsouyannopoulos, V., Vayonas, G., \& Tsoubaris, P. (2000). Chemical quality of hemodialysis water in Greece: A multicenter study. Dialysis \& transplantation, 29(9), 519525.

14. Perez, P. S., Barril, C. G., \& Del Rey, R. C. (2008). Monitoring on-line treated water and dialysate quality. Nefrologia, 28, 493-504.

15. Pirsaheb, M., Sharafie, K., Naderi, S., Ghafari, H. R., \& Khosravi, T. (2017). Role of reverse osmosis membranes on the concentration fluctuations of heavy metals in used water by dialysis instrument of hemodialysis patients. Annals of Tropical Medicine and Public Health, 10(4), 1019.

16. Coulliette, A. D., \& Arduino, M. J. (2013, July). Hemodialysis and water quality. In Seminars in dialysis (Vol. 26, No. 4, pp. 427-438). 